\title{
HOLISTIC APPROACH TO DEVELOPING TEXTBOOKS FOR CHILDREN-BEGINNERS IN PIANO PLAYING
}

\begin{abstract}
The paper presents a summary of a four-year long research on the text books in piano playing for the beginners. On the one hand, today, changes in paradigms are discussed much about (child-centered education), national standards are defined and author programmes have been developed by teachers; on the other hand, teaching aids adequate to the new paradigm and aimed at promoting 5-7 year old children's education in piano playing do not exist. The Aim of the Study is to formulate holistic approach-based principles that would underlie the development of a contemporary, scientifically valid teaching aid in piano playing for 5-7 year old children. Research subject: holistic approach to the development of a teaching aid in piano playing for 5-7 year old children. Research object: principles of developing a teaching aid.

The research results in defining the holistic approach-based principles for developing a teaching aid: gradualness, visuality, musical diversity, compactness, regularity, esthetics, national/ multinational principle, perceptibility, adequacy to the age, self-creation and scientific principle. On the basis of these principles, a text book for 5-7 year old children has been designed by the author and assessed by experts.

The research data are analyzed both qualitatively (surveys of teachers and pupils'parents) and quantitatively (method of experts' conclusions).

A textbook could help to comprehend what is happening at music lessons and easier join the piano training process, and it could also make the piano training process, whose participants are children, teachers and parents, more diverse and creative.

Keywords: piano playing, teaching aid, beginner in instrument playing, holistic approach
\end{abstract}

\section{INTRODUCTION}

The process of teaching/learning is unthinkable without textbooks. A textbook is still important at any level of education - in pre-school, primary school, higher education establishment and for life-long education as well. A textbook is vital not only for learners, but for their parents and teachers too.

The changes in education paradigms make the society aware of the fact that education is a continuous process, that any child can realize one's "Self", that competition is replaced by cooperation and that individual growth of each child is important.

M. Sîle recommends that the individual development of a child "should be oriented towards the needs of a child of a particular cultural environment" (Sīle, 2001, 3). Consequently, at compiling a textbook, holistic principles should be taken into consideration and familiar compositions, songs, rebuses and rhythm exercises should be selected, so that at the initial stage of learning piano playing a child would be able to use a book containing a familiar music material in Latvian.

Therefore the work on the textbook began already while conducting research during 
master studies, and it is reflected in the master thesis written by the author (Zìmele, 2008). The research showed that teachers in Latvia use five books available in Latvian:

V. Zosts, I. Zāne, I. Kalniņš „Klavieru spēles skola” (1953; 1994);

A. Žilinskis „Klavierspēles skola” (1935; 1938; 1942; 1947; 1992);

A. Vītoliņš ,Dziedāsim, rotāsim” (1964-1969; 1991);

B. Ozoliņa, T. Rozenberga „Pirmie soḷi klavierspēlē” (1999);

G. Melbārde, M. Sīle „Klavierspēles ābece” (1997; 2007).

Historically, textbooks on piano playing for beginners in Latvia have been explored by Maruta Sīle, a scholar in music pedagogy (Sīle, 2003). In her research "Klavierspēles skolas attīstība" (Development of the Piano School) the author has looked at the books published within the period of 1918-1940. However the society has undergone many changes since that time and therefore the textbooks on piano playing are now studied from the viewpoints of teachers and those of children's parents as well.

This problem became topical due to the following reasons:

- in Latvia, the problems of textbooks on piano playing, principles of their development and criteria for their assessment have not been explored;

- the basic education is planned to begin at the age of six (this implies that in case of the reform, the children of this age will begin learning music at general education schools offering in-depth music studies);

- lack of a contemporary teaching aid in Latvian;

- in Latvia, there is no research on current situation in the field of teaching aids for beginners in piano playing.

\section{THE AIM OF THE STUDY}

To formulate holistic approach-based principles for developing a contemporary, scientifically valid teaching aid.

\section{MATERIALS AND METOHDS}

SUBSTANTION FOR THE SELECTION OF A HOLISTIC APPROACH

The teaching aid "Klavierspēles ābecīte DoReMi" was compiled on the basis of a reference system or the approach that complied with the aims and tasks of the book - holism. Such approach was chosen because the author's purpose was to seek for solutions which would make the teaching aid explicitly purposeful philosophically and didactically.

The notions "holisms, veselums, kopveselums" (holism, wholeness) used in Latvian pedagogy express the same idea represented in three different words in Latvian. Though in this paper all three are mentioned, the principal notion used in the research will be "holism". It should be pointed out that in scientific papers the word "holistic" is quite frequently used as a synonym for a comprehensive vision, for things taken as the whole, taken in their totality, rather than as an isolated philosophical notion. The whole consists of parts, but the structure consists of components, and neither in science nor in practice does this imply one and the same thing.

Holistic approach to a teaching process is compared with moving along the spiral where the wholeness interchanges with parts, and those in their turn form the wholeness (Boardman, 1992).

Wholeness (Lieǵeniece, 1999; Kandavniece, 2006) treats pedagogical phenomena in their totality, sees them as something whole, thereby this approach has summarized the ideas about wholeness. It treats the tasks of education and a human being as such in their wholeness, where various systems are combined in a single totality (Lieǵeniece, 1999). 
A. Kandavniece writes about the structure of the wholeness: “...the integrated whole or the wholeness implies that there exists a certain structure of the wholeness (components), consequently, there is an analytical aspect in the evaluation of multiform inter-relations of any phenomenon" (Kandavniece, 2006, 120).

In music pedagogy the notion "wholeness" is used by M. Sīle. She treats wholeness as a unity of diversities via child's personality, which is a kind of wholeness in the process of selfrealization (Sīle, 2001).

In the art of music, for S. Feingold the totality of musical hearing, understanding of music, the technique of playing and sense of music of a musical personality is holistic (Feingold, 2002).

On summarizing the above mentioned, we can infer that the authors see holism as a continuous motion of a human, system or structure along one trajectory, but at any of its turn they encounter new tasks and challenges, which changing a human, change the whole system, and in its turn the changing system can make an impact on a human.

Two state ministries (the Ministry of Education and Science and the Ministry of Culture) are responsible for piano teaching at schools, which leads to the situation that the documents setting out what, when and how the piano playing should be taught are different. The Ministry of Education and Science is responsible for the general education schools offering in-depth music studies. As the number of such schools is not great (a little bit more than 15) (Malkova, 2011), this subject does not have its own standard, but each school develops its own standard taking the standard of the subject "music" as the basis. Then the ministry confirms the standard of each school. The Ministry of Culture is responsible for music schools where professionally-oriented curricula are implemented. Music schools follow the curricula recommended by the Department of Cultural Education and Creative Industry (DCECI) at the Ministry of Culture.

The comparison of these standards and curricula shows that basically they include the same things. The structure of both standards and curricula is identical: they comprise the aim, tasks and a compulsory content. Though the aims of all standards and curricula include the development of creativity, it is not reflected in the tasks of school standards defined by the Ministry of Education and Science. For instance, the standard of Riga secondary school Nr 88 focuses on the integration processes in society, while Riga secondary school $\mathrm{Nr} 45$ standard - on training amateur musicians. The curriculum for music schools recommended by DCECI is aimed at continuing the professional education at the next stage of education. The standards and the curriculum have the similar number of tasks (three; four). The common features of tasks are: mastering of basic skills of piano playing, the acquisition of elements of music language. The difference lies in collective music making which is included in the standard of secondary school $\mathrm{Nr} 45$ and in the curriculum of DCECI, but is not mentioned in the curriculum of secondary school $\mathrm{Nr} 88$.

However, at analyzing the compulsory content of the subject we see that the component creativity is included in the notions creative activities in the process of mastering piano playing, practical creative activity and musical creative activity.

The component the language of music or the acquisition of music language has been incorporated in the compulsory content of all standards and curricula. The standards of schools of the Ministry of Education and Science (MES) have separate components music - a component of culture and musical instrument playing as a component of culture. The component which is not emphasized in MES school standards but is included only in DCECI curriculum is the component music perception which incorporates the development of musical abilities, psycho-motor abilities 
and musical memory.

\section{SUBSTANTION OF THE DEVELOPMENT OF A TEXTBOOK}

In order to implement the general education school standards and respective curricula, the Ministry of Education and Science and book publishers have developed the criteria for evaluating textbooks, basic principles of textbook quality, general pedagogical criteria of evaluation, evaluation indicators, assessment indicators and criteria.

In 2009, Zvaigzne “ABC" publishers' Group for the Development and Quality of Textbooks has worked out basic principles of textbook quality using "Recommendations for the Developers and Evaluators of Teaching Literature" issued by the MES Education Content and Examination Centre, Assessment Criteria for Encased Sets worked out by the MES, criteria for textbook quality standards defined by European Educational Publishers group, conclusions of EEPG Best Schoolbook Award international jury and recommendations of the Centre for Educational Studies and Consultancy as the basis. These basic principles are applicable when developing a textbook and when assessing it. The basic principles include such sections as:

1. Quality of textbook content:

- the selection of the textbook content;

- the layout of the textbook content;

- the textbook - a set and supplementary materials;

- cultural function of the textbook content.

2. The textbook content and pedagogical approach:

- aims;

- tasks;

- training process monitoring;

- promoting the understanding of teaching materials.

3. Design, artistic setting and format of the textbook:

- format and polygraphy;

- font and text display;

- visual design.

Possibly, this is the optimal variant because in scientific literature misunderstandings occur when the author of the book writes about the evaluation indicators of the textbook, but the reviewer treats them as the principles of the development of books.

The State Center for Education Content (SCEC) has conducted research on "The development and evaluation of the content of teaching literature that complies with the State General Education Standards" (2010) where 10 didactic principles of the development of the teaching aid content are defined (however, these didactic principles include training content rather than the teaching aid as a whole where the section of polygraphy is important) (see Table 2).

When the textbook on piano playing was developed, these principles appeared to be too general (they did not emphasize the specificity of piano playing and pre-school age peculiarities). Therefore, at developing the textbook on piano playing "Klavierspēles ābecīte DoReMi", carrying out the survey among the piano teachers (Zìmele-Šteina, 2011d, 2012) and the survey among the parents of instrument playing learners (Zīmele-Šteina, 2011b) as well as using philosophy of holism as the basis, the author of this paper has worked out the principles of developing textbooks on piano playing for 5-7 year-old children (see Table 2).

\section{Table 2. Principles of developing teaching aids}




\begin{tabular}{|c|c|}
\hline $\begin{array}{l}\text { Didactic principles of the development of teaching } \\
\text { aid content formulated by SCEC }\end{array}$ & $\begin{array}{l}\text { Principles of developing a textbook on } \\
\text { piano playing for 5-7 year-old children } \\
\text { worked out by I. Zīmele-Šteina }\end{array}$ \\
\hline $\begin{array}{l}\text { 1. Purposefulness; } \\
\text { 2. Compliance with the peculiarities of the } \\
\text { development of Learner's perception } \\
\text { (comprehensibility); } \\
\text { 3. Scientific validity; } \\
\text { 4. Systematism; } \\
\text { 5. Regularity; } \\
\text { 6. Consecutiveness and succession (or modulation); } \\
\text { 7. Objectivity; } \\
\text { 8. Visuality; } \\
\text { 9. Relatedness to life; } \\
\text { 10. Cultural education. }\end{array}$ & $\begin{array}{l}\text { 1. Visuality; } \\
\text { 2. Gradualness; } \\
\text { 3. Musical material diversity; } \\
\text { 4. Compactness; } \\
\text { 5. Regularity; } \\
\text { 6. Esthetics; } \\
\text { 7. the national -multinational; } \\
\text { 8. Perceptibility; } \\
\text { 9. Conformity with age; } \\
\text { 10. Self-creation; } \\
\text { 11. Scientific validity. }\end{array}$ \\
\hline
\end{tabular}

The principles of developing a teaching aid worked out by the author of the paper are based on the specificity of the subject (individual lessons) and the learners (who are not only 5-7 year-old children, but also their parents). The creative properties of the subject are taken into consideration (at teaching piano playing to 5-7 year-old children, drawing, movements are involved alongside playing). Each of the developed principles is equally important, and taken together they form a single whole.

PRINCIPLES OF THE DEVELOPMENT OF HOLISTIC TEACHING AID ON PIANO PLAYING AND THEIR CHARACTERIZATION

\section{A. Principle of Visuality}

A teaching aid should be comprehensible for its user - the child. Since the main type of perception for a child is visual, the principle of visuality should be applied when a textbook is developed for them.

The principle of visuality deserved the greatest number of comments in teachers' survey. From 120 answers to the open question concerning an ideal teaching aid, everything that could be attributed to the principle of visuality was mentioned in 46 cases (drawings, illustrations, colorfulness, visual attractiveness). Teachers pointed it out in the following way: "big notes one composition on one page", "notes and letters sufficiently big to be easy for a small learner" (Zīmele-Šteina, 2011d).

This teachers' opinion is supported by the results obtained from the analysis of piano schools created by Latvian authors, made in 2010 (Zīmele-Šteina, 2011c), where a visual component is identified as essential for developing a textbook on piano playing for 5-7 year-old children. In parents' survey, this opinion is supported by the indicator ranked by the parents as the ninth (out of 41) "a book having big letters and notes" ( $\mathrm{n}=28-55 \%$ ) (Zīmele-Šteina, $2011 \mathrm{~b}$ ).

"Klavierspēles ābecīte DoReMi", which the author has developed within the period of 2009-2011, has notes bigger than usual, on one page there is one or two compositions. The book is colorful, bright colors have been used and each page has slight tonality.

\section{B. Principle of Gradualness}

This principle requires laying the material out according to the degree of the complexity of compositions or exercises. Gradualness implies having a sufficient number of compositions 
which help to learn new themes and then to reinforce them by the sufficient number of compositions of equal difficulty. The results yielded by the teachers' surveys (Zīmele-Šteina, 2011d) allow us to infer that the principle of gradualness is significant for developing textbooks on piano playing for the beginners, and the teachers' answers testify to this fact: "the compositions are arranged so that the degree of difficulty gradually increases", "small steps in increasing difficulty", "the note material is arranged consecutively according to the degree of difficulty".

In "Klavierspēles ābecite DoReMi" the notes in two octaves are acquired gradually: bass clef in the small octave and treble clef in the first octave. Step by step, a child learns clefs, fingering, length of notes, names of notes on the staff, notes on the keyboard, alteration signs. The child is introduced to melody transposing and note grouping.

\section{Principle of Musical Material Diversity}

With time, the repertoire changes and broadens, new colors are added and rhythm diversity is created. Many teachers still hold the opinion that jazz, rock and popular music are not intended for traditional piano playing, and broadening the repertoire at the expense of such music should not be supported. The research on teachers' and parents' desires and priorities relating to the training content of piano playing (Maļkova, 2011) identifies obvious differences: the parents rank mastering of popular, jazz music as the first, while the teachers - as the fourth respectively; the teachers rank mastering of classical music as the sixth, but the parents - only as the last - the tenth.

We can fully agree with D. Zariņš (Zariņš, 2003) that such musical experience is already being shaped in the family. However it would be wrong to say that when selecting music, teachers do not take parents', and consequently also children's, interests into consideration. Teachers, too, point out the necessity to have "compositions of various character-songs with the text, classical compositions, modern pop-music melodies” (Zīmele-Šteina, 2011d).

On the whole, in "Klavierspēles ābecīte DoReMi" 88 melodies have been included from which 39 are Latvian folk melodies, but there are also German, English, Hungarian, Polish, Russian etc. folk melodies and some author's compositions as well.

\section{Principle of Compactness}

There are lots of useful, attractive and emotionally rich compositions in the world of music, however the application of the principle of compactness would solve the problem of how to find the golden mean among that great variety of compositions, so that not to include all compositions into one book and thus make it too heavy for a 5-7 year-old child.

Trying to meet teachers' wishes the book should contain "both necessary and attractive materials" as well as illustrate everything - "compositions, drawings, exercises, work tasks".

Though more than 100 melodies (including finger exercises based on melodies of various nations and authors) are included in "Klavierspēles ābecite DoReMi" the format of the textbook is smaller than A4 and it has 120 pages. Consequently the book is not too heavy for a 5-7 yearold child.

\section{E. Principle of Regularity}

When developing a textbook on piano playing for the beginners the continuity of the training process has to be taken into account. Teachers mention it as a systematic transition "from what is easier to what is more difficult" (Zīmele-Šteina, 2011d).

In our practice we frequently hear that what has been done during classroom activities is unsuccessfully transformed at fulfilling home assignments. Thus, if everything done in the classroom has not been well reinforced or if the time period between the lessons has been long (during holidays or child's illness), at the next lesson the musical composition is performed with 
already "drilled" mistakes. To avoid such mistakes, listening to recordings of compositions to be learnt is very useful.

In "Klavierspēles ābecīte DoReMi" the musical material is supplemented by theoretical tasks, rebuses on the respective music, where the name of the note can be used to form a word (e.g., two notes- si and la - form the genitive case of the word "sils"). To reinforce, for instance, the note do four compositions are included in the book. The same concerns teaching of other notes - the opportunity is given to make a choice between four/five compositions, which all can be also used for reinforcing the material.

\section{F. Principle of Esthetics}

Music being undeniably one kind of art and piano playing - one of the most creative subjects, the principle of esthetics is very essential at developing a textbook on piano playing for 5-7 year-old children. The principle of esthetics is applied here in two aspects - didactic and polygraphic.

In teachers' survey (Zīmele-Šteina, 2011d) it has been characterized in the following way: "high-quality music", "compositions pleasant to ear", "beautiful accompaniments, which refine children's musical taste”, "the covers of notes should be of good quality".

In parents' surveys, where 101 parents of children learning instrument playing were involved, the parents shared their memories about their first textbook (on different subjects). It turned out that one third of parents mentioned "ABC" "with a big cock on the cover".

The compositions included in "Klavierspēles ābecīte DoReMi" have two kinds of accompaniment: one accompaniment is written in notes, the other is provided in CD.

The book has a spiral binding so that it should not close up when placed on the piano and should be conveniently open when doing written tasks and exercises. The covers have stave to draw notes on.

\section{G. Principle of the National-Multinational}

This principle, too, is treated from two angles. One of them is the diversification of the repertoire by "songs of various nations" (selection of the training repertoire) and the other is the issue of the language of the textbook.

The results of the teachers' survey (Zīmele-Šteina, 2011d) testify to the fact that at present there is an urgent need for a textbook in Latvian for the beginners in piano playing. To maintain the interest in piano playing a repertoire of diverse music is needed, however Latvian folk songs are necessary to strengthen both national spirit and national identity.

The idea about the necessity for a bilingual textbook "In Latvian and in Russian" was expressed in teachers' survey, but as it was mentioned above, the lack of books in Latvian remains the main problem at present and therefore bilingualism won't be analyzed in detail and won't be applied at developing new teaching aids.

"Klavierspēles ābecîte DoReMi" is in Latvian, but at the same time folk songs of six different nations are included in this book, moreover, one Latgalian folk song with the text in the Latgalian dialect has been also inserted in it.

\section{H. Principle of Perceptibility}

To make the perception of the textbook material easier, the layout, size of the notes/ letters and respective drawings should be paid great attention to, because they help to understand aims set in the compositions and exercises. Both children ("a textbook written in the language attractive for children") and their parents and teachers need an easily perceptible textbook ("easily comprehensible" [textbook]") (Zīmele-Šteina, 2011d). 
At determining the basic priorities, the parents pointed out such three indicators:

- Comprehensible for children, so that they could understand everything without parents' help $(n=41-82$ per cent);

- Comprehensible for parents, so that they could help ( $n=36-73$ per cent);

- Comprehensible for teachers, so that they could explain everything ( $n=34-67$ per cent) (Zīmele-Šteina, 2011b).

Drawings in "Klavierspēles ābecīte DoReMi" not only illustrate the essence of the composition, but they also either attract children's attention to a new theme or reinforce children's knowledge in piano playing (e.g., to find and write down the notes on which a small bear has left its sweet footprints - there is a keyboard with a drawing of a small bear holding a honey pot, but the notes on the keyboard have footprints of the bear drawn on them).

\section{Principle of Conformity with Age}

One of the basic principles in pedagogy is taking the peculiarities of age into account. These peculiarities commonly determine the workload, learner's working and rest regime, arrangement of subjects, materials for the subject and teaching forms and methods as well (Vourinens, Tunala, 1999).

In the survey concerning an ideal teaching aid, teachers state that if the principle of conformity with children's age is applied, the ideal teaching aid is: "easily comprehensible for a child" and "having small tasks which comply with the age of a child" (Zìmele-Šteina, 2011d). Parents wish the textbook would be comprehensible for children so that they could understand everything without parents' help ( $\mathrm{n}=41-82$ per cent). From 41 indicators offered, this indicator was ranked as the second one (Zīmele-Šteina, 2011b).

If a teacher knows the psychological peculiarities of a respective age group it easier for him to stimulate a child for achieving the given aim.

In "Klavierspēles ābecitte DoReMi" the description of tasks for children is short and concise and is written in capital letters only. The book has a horizontal lay-out so that all notes and descriptions could be easily seen. To attract and hold children's attention, the book is compiled so that various methods - to play, exchange roles, to listen, to write, to clap etc. - can be used during the lessons.

\section{J. Principle of Self-Creation}

This principle is concerned with active participation in developing and enriching the textbook. The answers of teachers relating to this principle suggest that teachers support the idea about individual approach to children, and that each child needs various multiform tasks and compositions. Therefore teachers are for "the opportunity for a teacher to arrange the succession for each learner individually" and "give preference to various individual combinations".

In this case we can speak about teacher's creativity and self-creation: " a folder containing exercises and compositions from different sources, listed by a teacher himself and according to his own choice, is compiled methodologically correctly". Such teacher's created teaching aid developed for each child individually could be like "a folder which helps a teacher to complete his own collection" (Zīmele-Šteina, 2011d). Therefore a teacher has to attentively follow the individual development of a child and use even a ready-made teaching material (textbook) creatively.

In the questionnaire filled in by the learners' parents, the possibility for a learner to draw notes himself (e.g., a laminated music paper for work at the lesson), among 41 indicators offered, ranks as 17 ( $\mathrm{n}=22-43$ per cent) (Zīmele-Šteina, 2011b). 
The textbook "Klavierspēles ābecìte DoReMi" offers a possibility for a teacher to supplement it according to the individual development level of a child. Fingering is not marked until page 45 . It has to be done either by a teacher or by a child oneself. This helps a child to comprehend the principles of fingering and be a co-author of the book.

\section{K. Principle of Scientific Validity}

The principle of scientific validity in a teaching aid on piano playing for the beginners is manifested in the correctness of reflecting music theory as well as in the accuracy of the given facts and simplicity of their interpretation, which corresponds to the age group of a child. At developing a textbook, this principle involves compliance of the book with the holistic approach, and also the use of the latest approaches and theories in psychology, pedagogy and musicology as the basis.

When compiling a textbook for children of senior pre-school age and junior school-age (5-7 year-old children), the necessity arises to employ the results yielded by the research on the opinions of teachers and parents, since parents and teachers best of all realize children's desire to play contemporary compositions, have opportunities to practice and understand their interests and needs.

"Klavierspēles ābecīte DoReMi" was developed on the basis of research conducted on the holistic approach to developing a teaching aid (Zīmele, 2008; Zīmele-ŠSteina, 2009a, 2009b, 2010a, 2010b, 2011a, 2011b, 2011c, 2011d, 2011e, 2012). The results of this research have been presented at 10 international conferences within the period of four years. The self-reflection of piano teacher's experience gained by the author is also included in the book.

\section{CONCLUSIONS}

The holistic approach to developing teaching aids is necessary to overcome drawbacks identified in the current teaching aids and to broaden the outlook on teaching piano playing (including that of instrument playing).

Holistic principles: visuality, gradualness, diversity of musical material, compactness, regularity, esthetics, the national-multinational, perceptibility, conformity with age, self-creation, scientific validity - have been selected for the development of a teaching aid on piano playing for 5-7 year-old children so that this textbook should contribute to the development of child's piano skills and teachers would be given the opportunities to diversify the teaching methods.

A textbook created on the basis of the holistic approach could help the parents to better comprehend what is happening at music lessons and thus easier join the piano training process, and it could also make the piano training process, whose participants are children, teachers and parents, more diverse and creative.

\section{Acknowledgement}

This study was supported by ESF project "Support to Implementation of Doctoral Studies at Daugavpils University” (agreement No.2009/0140/1DP/1.1.2.1.2/09/IPIA/VIAA/015) 


\section{REFERENCES}

Boardman, E. (1992). New environments for teacher education: Eunice Boardman discusses a holistic approach to teaching and its implications for change in the teacher education curriculum. Music Educators Journal, $79,41-43$.

Feingold, S. (2002). The preparation of a holistic musician: Developing a musical ear, musical understanding and sensitivity to music in instrumental music lessons. International Journal of Music Education, 39 (2) 97-111.

Kandavniece, A. (2006). Kustību rotaļas programmas apguve kopveseluma skatījumā [Acquisition of movement games on holistic principles]. Theory for practice in the Education of Contemporary Society: $2^{\text {th }}$ International Scientific Conference. Riga: Rīgas Pedagoǵijas un izglīīibas vadības akadēmija, 120-126 (in Latvian).

Lieǵeniece, D. (1999). Kopveseluma pieeja bērnu audzināšanā (5-7 gadu vecumā) [Wholistic approach in children's upbringing (5-7 years of age)]. Rìga: Raka. (in Latvian).

Maļkova, L. (2011). Skolēnu kreativitātes att̄istības veicināšana klavierspēles apguves procesā [Enhancing the development of learners' craetivity at mastering piano playing]. Zinātnisko rakstu krājums Radoša personība 9 (130-138). Rīga: RaKa. (in Latvian).

Sīle, M. (2001). Veseluma pieeja bērna personības attīstībā klavierspēles mācību procesā [Holistic approach to the development of child's personality in piano training process]. (Unpublished doctoral dissertation, Latvian University, Riga, Latvia.) (in Latvian).

Sīle, M. (2003). Latvijas klavierspēles skolas attīstība [The Development of Latvian Piano Playing School]. Rīga: RaKa, 145 lpp. (in Latvian).

Vuorinens, R., Tūnala, E. (1999). Psihologijas pamati. Cilvēka attīstības posmi. [Fundamentals of Psychology]. Rīga: Zvaigzne, 198. lpp. (in Latvian).

Zariņš, D. (2003). Mūzikas pedagoǵijas pamati [Fundamentals of music pedagogy]. Rīga: RaKa, 200 lpp. (in Latvian).

Zìmele, I. (2008). Mācību satura izveide klavierspèle 5-6-7 gadus veciem bèrniem [The development of the training content in piano playing for 5-6-7 year-old children]. Master Thesis. Daugavpils: Daugavpils Universitāte, 94 lpp. (in Latvian).

Zīmele-Šteina, I. (2009a). Contemporary content for piano playing with beginners in Latvia as viewed from sustainable perspective. Proceedings of the $6^{\text {th }}$ International Conference Person. Color. Nature. Music (pp. 41-42). Daugavpils: Saule.

Zīmele-Šteina, I. (2009b). Designing the study content for teaching piano playing to 5-7 year old children. In J. Davidova (Ed.), Proceedings of the $6^{\text {th }}$ International Scientific Conference Problems in Music Pedagogy (pp. 249-358). Daugavpils: Daugavpils University.

Zìmele-Šteina, I. (2010a). The evaluation of the Baltic State Piano playing textbook for beginners by applying EEPG quality principles of textbook evaluation. In T. Selke, G. Lock \& M. Moistlik (Eds.), Evaluation, reflectivity and teaching methodologies in the framework of multi-cultural understanding (pp. 81-83). Tallinn: Tallinn University Institute of Fine Arts, Department of Music \& MEYTT.

Zīmele-Šteina, I. (2010b). Pedagogical principals and the classification of educational materials. Proceedings of the $5^{\text {th }}$ International scientific conference Theory for practice in the education of contemporary society (pp. 476-481). Rīga: Rīgas Pedagoǵijas un izglìtības vadības akadēmija.

Zìmele-Šteina, I. (2011a). Piano playing textbooks for novices in the Baltic States: Critical analysis. In G. Tchibozo, (Ed.), Proceedings of the $3^{\text {rd }}$ Paris International conference on education, economy and society (pp. 641-650). Strasbourg, France: Analytrics.

Zīmele-Šteina, I. (2011b). The opinion of Latvian pre-school and first-form pupils' parents about textbooks on instrument playing. In J. Davidova (Ed.), Proceedings of the $7^{\text {th }}$ International Scientific Conference Problems in Music Pedagogy. Daugavpils: Daugavpils University. 
Zīmele-Šteina, I. (2011c). Methodological analysis of Latvian national schools of piano playing. In H. Ruismaki \& I. Ruokonen (Eds.), Arts and skills - sourse of well-being (pp. 203-212). Helsinki: University of Helsinki.

Zīmele-Šteina, I. (2011d). Opinions of Latvia's piano teachers about ideal study aid for the current situation and future prospects. Proceedings of the $9^{\text {th }}$ international JTSFS/BBCC Conference Sustainable development. Cultur. Education (p. 58). Šiauliai: Šiauliu universiteto leidykla.

Zīmele-Šteina, I. (2011e). Presence of holism in contemporary textbooks on piano playing for beginners in Latvia. $11^{\text {th }}$ International conference on Textbooks\& Educational media. "Representation of otherness", 28-30 September, 2011. Kaunas, Lithuania.

Zīmele-Šteina, I. (2012). Piano playing teaching aids for beginners: Analysis of the current situation and future prospects. In A. Șlahova (Ed.), Scientific articles of $7^{\text {th }}$ international Conference Person. Color. Nature. Music (pp. 286-295). Daugavpils: Daugavpils University Academic Press “Saule".

Mg. paed. Ineta Zīmele-Šteina

Daugavpils University

Address: Brīvības gatve 443-5, Rīga LV-1024, Latvia

Phone mob.: +37129220143

E-mail: inetazimelesteina@gmail.com 